\title{
Health Information Systems in the Decision-Making Process in Primary Care
}

\section{Ericka Silva Holmes ${ }^{1}$, Sérgio Ribeiro dos Santos², Alexandra Fraga Almeida ${ }^{3}$,} Jéssica Helena Dantas de Oliveira ${ }^{4}$, Gyl Dayara Alves de Carvalho ${ }^{5}$, Leila de Cássia Tavares da Fonsêca ${ }^{6}$, Maria Bernadete de Sousa Costa ${ }^{6}$, Juliana Barbosa Medeiros ${ }^{4}$, Eufrásio de Andrade Lima Neto ${ }^{7}$

\section{Abstract}

Objective: Identifying the scientific literature about the use of health information systems, their weaknesses and potential for decision-making.

Method: A systematic literature review study conducted in September/October 2014. The sample consisted of 13 articles published in the databases: LILLACS, SciELO, PubMed, Cochrane.

Results: There was a small number of publications about the subject; it was pointed out as weaknesses for use of the systems: unpreparedness of the professionals, lack of training, poor access to systems; and how potential: characterization of the population profile, epidemiological, people's living conditions, etc.

Conclusion: The health information systems provide great potential for decision-making and must overcome difficulties to use, being necessary to carry out more studies about the subject.

\section{Keywords}

Information Systems; Primary Health Care; Health Management; Health Manager.

\section{Introdution}

Systems Health Information (SIS) constitute a set of components that work seamlessly as a data collection mechanism, processing, analysis
1 Nurse. Master's Program Graduate Program in Health and Decision Models (PPGMDS/UFPB). Member of the Group of Studies and Research in Management and Information Technology in Health (GEPAI/UFPB). João Pessoa - PB. Brazil.

2 Department of Clinical Nursing at the Federal University of Paraíba. Group Coordinator of Study and Research in Management and Information Technology in Health (GEPAIE). João Pessoa, Brazil.

3 Nurse. Audit Specialist Hospital. Member of the Group of Studies and Research in Management and Information Technology in Health (GEPAIE/UFPB). João Pessoa - PB. Brazil.

4 Nurse. Member of the Group of Studies and Research in Management and Information Technology in Health (GEPAIE/UFPB). João Pessoa - PB. Brazil.

5 Nurse. Master's Graduate Program in Nursing at the Federal University of Paraíba. Member of the Group of Studies and Research in Management and Information Technology in Health (GEPAIE/UFPB). Joao Pessoa - PB. Brazil.

6 Department of Clinical Nursing DENC/UFPB. Researcher of the Group of Studies and Research in Management and Information in Nursing GEPAIE/UFPB. João Pessoa - PB. Brazil.

7 Statistical. Department of Statistics, Federal University of Paraíba, João Pessoa-PB. Brazil.

\section{Contact information:}

\section{Ericka Silva Holmes.}

Address: Street Penha Emília da Silva, $n^{\circ}$ 47, apt. 204. José Américo. João Pessoa-PB, Brazil. CEP: 58074-158.

Đ ericka_holmes@hotmail.com 
and transmission of information, as well as research and planning in disease control, able to structure, operational, supervise, monitor and evaluate the performance and quality of health services, producing the necessary information for the decision process of these services. [1, 2]

In 1998, the Department of Primary Health Care Department of the Ministry of Health and the Department of Computer and Information of the National Health System (DATASUS) inaugurated the Information System of Primary Care (SIAB). Through this system, it had knowledge of population indicators (morbidity, mortality, and services) of a specific area, thus facilitating the achievement of the health diagnosis, planning and evaluation of actions in health primary care teams. In addition, this system includes administrative background information, making it essential for decision-making. [3]

Thus, the SIAB was created to provide operational and managerial support to the work of data collection of the Family Health Strategy (ESF), providing information to managers in order to facilitate and expedite the decision-making process. $[4,5]$

However, some difficulties have been raised in the course of its use, starting with data collection, which was characterized as a step that had major deficiencies, bringing in some way negative, since the guarantee of quality information is condition essential for objective analysis of health status, health actions programming and also for making evidencebased decisions. [6]

Study also points out that in general there is an acceptance of the professionals in relation to computing resources that the Health Information Systems contemplate. This resistance is given by different factors such as a lack of information about the true purpose of information systems, lack of adequate training for health staff and the lack of motivation. [2]

In an attempt to minimize these problems in primary care, the Ministry of Health launched through
Ordinance $\mathrm{N}^{\circ} 1412$ of June 10, 2013, the establishment of the Health Information System for Primary Care (SISAB). This will be operationalized through the Department of Primary Care by e-SUS Primary, consisting of two systems: the Simplified Data Collection (CDS) and the Electronic medical records Citizen (PEC). [7]

Thus, the new system seeks to ensure the constant updating of easy access, allowing professionals to plan and organize their actions in their work processes, acquiring and applying knowledge and skills in their interventions, permeating the solution of the problems, quality of labor and employee. The use of information systems in the decisionmaking process increases the efficiency of services provided to customers therefore provides qualified and updated professionals to work in health services. [2]

Thus, it is clear that from the creation and implementation of new SIS, improvements are being made in the processing of data provided by the ESF, and thus a very important step forward for public health policies, since it guaranteed quality and reliability of the data will be decisions taken in health by the safer management. $[4,8]$

Allied to this context, the process of health decision-making is characterized by a chain of decisions, which are taken by people in different situations, it is necessary for it to formulate plans and interpretation of goals to be achieved, from an in-depth study of the problem through data collection and information from the SIS, which will require the knowledge of the best way forward. [9]

However, the management practice of the ESF territory has not yet expressed a definition and therefore struggling. In this sense, managing a territory requires professionals that add diverse knowledge and understands the social, political, cultural, epidemiological, ecological and historical region. 8 of the process of managing, when run properly is directed to the critical examination issues, problem solving and decision making. [10] 
Therefore, it is of fundamental importance that health information would make suggestions to build explanatory chain of information system problems, thus increasing the capacity of decision-making, since the information is essential to the decision, so that gives the manager knowledge of living conditions and health of the population. [10]

Thus, in view of the above and of the need for evaluation of the SIS as a support tool for the management and work of health professionals, this study seeks to reflect on the following problem: that scientific production is the use of health information systems for the decision-making process in primary care?

Thus, this study proposes the following objectives: to identify the scientific literature on the use of health information systems as well as the weaknesses and potential for the decision-making process.

\section{Method}

This is a systematic review study of literature, which is a form of research that uses literature as a source of data, obtaining them through an intervention strategy with application of explicit and systematic methods of search in order to identify issues that require further investigation, as well as the synthesis of information about a particular topic. [11]

To carry out the review, seven steps have been taken based on the Cochrane Handbook, described as: formulation of the scientific question, location and selection of studies, critical assessment of studies, data collection, analysis and presentation of data, data interpretation, enhancement and review update. [12]

This study was conducted with the participation of three researchers who evaluated independently, the quality of each article on the methodology adopted. To that end, we created a research protocol to be followed by all who submitted from local and ways to search until criteria for inclusion and exclusion, defining the outcomes of interest and finally the analysis of results.

With regard to the search performed the virtual databases were involved national and international scientific works published in online journals from August 2009 to September 2014, because it is the last five years of publications, which dealt with the use of health information systems for decision making in primary health care.

They were used for this: the Virtual Health Library $(\mathrm{VHL})$, whose database was used the Latin American and Caribbean Health Sciences (LILACS); the PubMed Library, whose database was the "Medical Literature Analysis and Retrieval System Online" (Medline); and the Cochrane Library.

The collection of data in the databases took place in August and September 2014. For the survey of journals were used the following descriptors in MeSH indexed in English, "information systems", "primary health care", "health management "; and in Portuguese: "information systems", "primary health care", "health management"; interspersed with the Boolean operator "AND".

For filtering and sample selection of journals there were established as selection criteria: full-text articles available and free, "free full text", published in August 2009 to September 2014, in Portuguese and English. Exclusion criteria were articles in duplicate published for over five years, in other languages, dissertations and theses in addition to those studies that did not address directly the issue in focus.

When conducting the search were raised 216 research articles on health information systems. Subsequently, filtering was carried out following the articles previously established selection criteria, as well as a thorough reading of studies chosen for each author, thus finalizing the choice of 13 studies in common by the three researchers. Please note that the selected papers presented their goals compatible with those of research, where the search strategy can be seen in Table 1. 
Table 1. Description of selected articles and their search modes.

\begin{tabular}{|l|c|c|c|}
\hline \multicolumn{1}{|c|}{ Search Mode } & Database & $\begin{array}{c}\text { Articles } \\
\text { Found }\end{array}$ & $\begin{array}{c}\text { Selected } \\
\text { articles }\end{array}$ \\
\hline $\begin{array}{l}\text { "Information systems" } \\
\text { AND "primary health }\end{array}$ & LILACS & 30 & 4 \\
\hline care" & SciELO & 0 & 0 \\
\hline and "health & PubMed & 6 & 0 \\
\hline management" & Cochrane & 5 & 0 \\
\hline "Information systems" & LILACS & 32 & 2 \\
\hline $\begin{array}{l}\text { and "primary health } \\
\text { care" }\end{array}$ & SciELO & 7 & 0 \\
\hline & PubMed & 38 & 2 \\
\hline "Information & Cochrane & 1 & 0 \\
\hline systems" and "health & LILACS & 13 & 2 \\
\hline management" & SciELO & 0 & 0 \\
\hline & PubMed & 17 & 1 \\
\hline Total & Cochrane & 1 & 0 \\
\hline "Primary health & LILACS & 55 & 1 \\
\hline care" and "health & SciELO & 4 & 0 \\
\hline management" & PubMed & 3 & 1 \\
\hline & Cochrane & 4 & 0 \\
\hline & & 216 & 13 \\
\hline
\end{tabular}

To perform the analysis of the articles it was built and used an instrument with the following categories: journal title, year of publication, type of study, vocational training's lead author, institution, approach, objectives, results and conclusions. The content analysis was developed in a systematic and critical way, as was carried out in-depth reading of the articles found.

\section{Results}

The results were extracted from 13 articles and found in the sample of this study. Although demand in the databases have been held in the databases LILACS, PubMed, SciELO and Cochrane; They considered only the periodicals found in LILACS and PubMed considering that only these have demonstrated compatibility with the research objectives.

As can be seen in Table 2, most of the produced articles were found in Brazil totaling 9 (69.23\%) studies; publications on SIS in primary care decision-

Table 2. Characterization of the selected articles on the publication year, journal, study site, and use of SIS in decision-making.

\begin{tabular}{|c|c|c|c|c|c|}
\hline $\mathbf{N}^{\circ}$ & $\begin{array}{c}\text { Year of } \\
\text { publication }\end{array}$ & Periodic & $\begin{array}{l}\text { Data } \\
\text { base }\end{array}$ & $\begin{array}{l}\text { Geographic } \\
\text { location }\end{array}$ & Title Study \\
\hline 1 & 2013 & Cogitare Enferm & LILACS & Brazil & $\begin{array}{l}\text { Primary care information system: potential and under- } \\
\text { utilization in decision-making }\end{array}$ \\
\hline 2 & 2013 & $\begin{array}{l}\text { Applied Clinical } \\
\text { Informatics }\end{array}$ & PubMed & Colombia & $\begin{array}{l}\text { An Information Systems Model of the Determinants of } \\
\text { Electronic Health Record Use }\end{array}$ \\
\hline 3 & 2012 & $\begin{array}{l}\text { Online Brazilian } \\
\text { Journal of Nusing }\end{array}$ & LILACS & Brazil & $\begin{array}{l}\text { Basic care information system as a management tool: a } \\
\text { case study in Santo Antonio de Jesus / BA }\end{array}$ \\
\hline 4 & 2012 & Croat Med J & PubMed & Croatia & $\begin{array}{l}\text { Users' satisfaction with the primary health care } \\
\text { information system in Croatia: a cross-sectional study }\end{array}$ \\
\hline 5 & 2012 & $\begin{array}{l}\text { AMIA Annu Symp } \\
\text { Proc }\end{array}$ & PubMed & USA & $\begin{array}{l}\text { Clinical Information System Services and Capabilities } \\
\text { Desired for Scalable, Standards-Based, Service-oriented } \\
\text { Decision Support: Consensus Assessment of the Health } \\
\text { Level } 7 \text { Clinical Decision Support Work Group }\end{array}$ \\
\hline 6 & 2012 & $\begin{array}{l}\text { Rev. Gaúcha } \\
\text { Enferm. }\end{array}$ & LILACS & Brazil & $\begin{array}{l}\text { Use Information System in the Family Health Strategy: } \\
\text { perceptions of nurses }\end{array}$ \\
\hline 7 & 2011 & $\begin{array}{l}\text { Rev. Panam salud } \\
\text { Publica }\end{array}$ & LILACS & Brazil & $\begin{array}{l}\text { Health information Area structure from the information } \\
\text { resources management: experience analysis }\end{array}$ \\
\hline
\end{tabular}




\begin{tabular}{|c|c|c|c|c|c|}
\hline $\mathbf{N}^{\circ}$ & $\begin{array}{c}\text { Year of } \\
\text { publication }\end{array}$ & Periodic & $\begin{array}{l}\text { Data } \\
\text { base }\end{array}$ & $\begin{array}{l}\text { Geographic } \\
\text { location }\end{array}$ & Title Study \\
\hline 8 & 2011 & Rev. Saude publica & LILACS & Brazil & Use of health information systems gauchos small towns \\
\hline 9 & 2010 & $\begin{array}{l}\text { Rev. Espaço para } \\
\text { Saúde }\end{array}$ & LILACS & Brazil & $\begin{array}{l}\text { Primary care information system and its use by the family } \\
\text { health team: an integrative review }\end{array}$ \\
\hline 10 & 2010 & $\begin{array}{l}\text { BMC Health } \\
\text { Services Research }\end{array}$ & PubMed & India & $\begin{array}{l}\text { Evaluation of computerized health management } \\
\text { information system for primary health care in rural India }\end{array}$ \\
\hline 11 & 2010 & $\begin{array}{l}\text { Rev. Baiana Saúde } \\
\text { Pública }\end{array}$ & LILACS & Brazil & $\begin{array}{l}\text { Using the Primary Care Information System (SIAB) for the } \\
\text { planning of actions by the teams of the Health Strategy } \\
\text { for the Municipality of Montes Claros Family (MG). }\end{array}$ \\
\hline 12 & 2010 & $\begin{array}{l}\text { Cien Cuidado } \\
\text { Saude }\end{array}$ & LILACS & Brazil & $\begin{array}{l}\text { Primary care information system - health status of a } \\
\text { municipality in Mato Grosso }\end{array}$ \\
\hline 13 & 2009 & Rev. APS & LILACS & Brazil & $\begin{array}{l}\text { Nursing management in Basic Units: information as a tool } \\
\text { for decision-making }\end{array}$ \\
\hline
\end{tabular}

Table 3. Relationship per article the use of health information systems in the decision-making process.

$\mathbf{N}^{\circ}$ Article Use of information systems in health decision-making

1 Important to the decision-making process in the administration or in patient care;

2 Supports the clinical data query service, the notification and user communication services

3 A tool for planning the activities and services offered in the health strategy unit of the family;

$4 \quad$ It saves time for health professionals on your record, maintenance and reporting

5 It reduces costs, improves the quality of medical care as supporting the electronic clinical decision and order entry also eliminates medication errors and reducing unnecessary tests;

6 Instrument for data collection, control and information as well as being a tool that aids in local diagnosis, helping to identify the community's health needs

$7 \quad$ Helped to change the care model from the integrated computerization of primary health care units;

8 Contributes to the understanding of the needs of municipalities and subsidizes decision-making in municipal management;

9 Tool to guide actions in accordance with local realities;

10 Ability to obtain specific information according to the needs of each healthcare professional

11 Household assessment, construction of health indicators, definition of priorities, work organization, local programming

12 Knowledge of health social reality accompanied population assessment and the adequacy of health services and their readjustment whenever necessary;

13 Essential support to the organization and management of services, management of health facilities

making process more were held in 2010 and 2012 with four (44.4\%).

For the construction of Table 3 were selected for each item, the features brought by these healthrelated decision-making, thereby addressing the vision brought by each study for this process.
Regarding the construction of Table 4, it was identified in the course of reading the articles some weaknesses and potential of information systems in health decision-making, and therefore listed. 
Table 4. Description of the weaknesses and potential of health information systems in the decision-making process found in the articles.

\begin{tabular}{|c|c|}
\hline Weaknesses & Potential \\
\hline $\begin{array}{l}\text { - The under-utilization of systems for directing the } \\
\text { - } \quad \text { Lack of training, support, and knowledge of } \\
\text { professionals to use the systems; } \\
\text { - The limitation of SIS found refers to the use of } \\
\text { strategic information to the long-term decision; } \\
\text { - Lack of mechanisms for evaluation and control of the } \\
\text { data produced; absence of popular participation in } \\
\text { the collection and use of information generated; } \\
\text { - } \text { - } \text { Incess difficulties to information systems; } \\
\text { information between different databases, and the } \\
\text { discrepancy between the statism of the data and the } \\
\text { dynamism of the local reality }\end{array}$ & $\begin{array}{l}\text { - It has great potential to contribute to the local } \\
\text { epidemiological surveillance; } \\
\text { - Fundamental to the implementation of planning, } \\
\text { monitoring and evaluation of health actions in the ESF; } \\
\text { - Collaborates so that the data are transformed into } \\
\text { information and then into knowledge for the health team; } \\
\text { - Features population profile, epidemiological and living } \\
\text { conditions of the population and quantitatively assesses } \\
\text { the production of USF services; } \\
\text { - It allows to evaluate the work performed and the adequacy } \\
\text { of health services; } \\
\text { - The SIS provide information about the population and } \\
\text { it can make a diagnosis of reality and intervene when } \\
\text { necessary; }\end{array}$ \\
\hline
\end{tabular}

\section{Discussion}

In health care, information systems are used to collect, store and disseminate data that can contribute to the planning and decision making. Currently, it is essential to modernize these systems in view of the intense structural, procedural and managerial changes in order to provide answers to the new and complex demands. These demands are mainly due to the organizational changes, which have intensified the flow of information required and therefore a decentralized decision-making process, requiring a more effective participation of the different stakeholders involved in decisions. [13]

In this sense it is essential that the information is located, accessible and meaningful data to build explicative chain of the health system or a territory problems, allowing to increase the capacity of decision-making, since knowing the living conditions and health of the population is a necessary step for assessing the impact of actions previously performed. [10]

The 13 articles in the sample of this study brought in general, the use of health information systems for decision making, in addition to the publication year of the features, periodic, authors and place of publication, article title and base data, as can be seen in Table 1.

Since the characteristics presented in Table $\mathbf{2}$ demonstrate the importance of using health information systems as a data collection tool and information about specific population by providing diagnosis of the health situation for holding actions and public health policies, since the information system can guide and support the implementation of strategies that seek to solve the problems found.

It is worth portray the process of working with managers during the management of health facilities, should focus on the SIS, contributing thus to the construction of local knowledge and collaborating directly to the implementation of a model of care that builds on the principles and SUS guidelines. [8]

However, it is known the existence of many weaknesses and difficulties to use such information systems. Some of the found studies revealed that among these weaknesses were highlighted underutilization of systems for directing the work; difficulty of access to information; lack of training, support, and knowledge of professionals to use the systems; limitation on the use of strategic information for making long-term decision; absence of evaluation 
mechanisms and control of the data produced; absence of popular participation in the collection and use of information generated; conceptual or geographic information incompatibilities between different databases, and the discrepancy between the statism of the data and the dynamism of the local reality. [14, 4, 13]

Another important fact is found that the high volume of data and information has caused difficulties for the management and care process, as health records are still guided predominantly by written culture providing poor information to drive management decisions; and support care activities. [13]

Municipalities face difficulties in developing its technical capabilities, thus assuming the role of mere collectors of data, which leads professionals to under-utilize information systems. SIS several initiatives of adaptation to changing needs is being undertaken; however, the diversity of Brazilian municipalities implies different possibilities for implementing health policies. [15]

The difficulties brought by the studies faced with the real objectives of the SIS. Every health manager needs updated, reliable and complete to be able to take appropriate decisions on the operations and performance of health activities and services under their responsibility, since the problems coping process, can make inferences, and plan, deploy and implement actions based on the information that is available. [10]

Opposing the difficulties encountered and weaknesses, research also shows strengths, identifying and indicating great potential brought by the SIS as characterizing the population profile, epidemiological and living conditions of the population; the quantitative assessment of the production of USF services; great potential for contribution to the local epidemiological surveillance; collaboration for the transformation of data into information and knowledge to those in the health teams; It allows the evaluation of the work and the adequacy of health services offered in addition to the implemen- tation of planning, monitoring and evaluation of health actions developed in the ESF. [4, 10, 16, 14] Yet the SAIS are important tools for collecting and tracking data to assist in the understanding of the needs of the people belonging to the territory of the health unit. From this information, professionals will be able to know what issues are really prevalent among families and, therefore, may carry out the planning of health actions. Thus, it can be said that the SIS become tools to support activities for decision making and acquisition of knowledge, resulting in more trained professionals, creative, able to change reality and improve the care of health services. [4]

It is clear that the use of information systems as an instrument of the family health team's work was instrumental in the identification and assessment of families in the construction of health indicators in setting priorities in the organization of work in local programming and direction of home visits. So the SIS has the power to assist the teams and health managers to define their priority groups through local diagnosis and plan the actions that would be implemented in teams. [16]

It adds that, through the information systems of primary care professionals can obtain, by means of information created, knowledge of what is happening with the client as well as situations that involve targeting interventions that lead to prevention and promotion of health. [13]

However, it is observed that the health information systems are little used and valued by professionals who use it, starting with the coordination of the ESF than the use of critical and reflective tool as management.16 A study of workers primary care shows that some dental and medical professionals use these systems, unlike the nurse uses the SIS as an analytical tool of health inspection and epidemiological situation, with diagnosis and action planning. [17] 


\section{Conclusion}

Based on these, sets up essential that professionals and health managers pay attention to this decisionmaking tool, since if used correctly will allow the transformation of data into information, which will generate knowledge appropriate to draw an effective planning for health decision-making, thereby promoting the solving of several problems.

SIS are characterized as important tools that assist in decision making based on knowledge from the interpretation of their information, thus enabling proper planning of care actions, sanitary partner, assessment of the local health situation among other actions aimed at proposing strategies for problem solving.

In this perspective this study identified 13 studies related to the use of these systems for decision making, and therefore a reduced number of publications, which implies the opportunity to conduct more studies on this theme.

Still, the analysis of the results shows that the SIS provide great potential for strategic planning in health, such as the contribution to epidemiological surveillance, planning and evaluation of health actions by the ESF and to other health agencies, as well as for adequacy of health services among other measures. However, such opportunities are devalued by most health professionals, which only refer to difficulties in handling and using this tool, indicating no training for use of systems, lack of support, lack of knowledge, difficulties of access, etc.

Thus, it highlights the need to invest in skills and expertise of managers and health professionals involved in this process, through the teaching-learning, skills and training, among other permanent activities for the strengthening of local management, of solving at work, the epidemiological assessment and relationship with reality.

\section{References}

1. Oliveira QC, Corrêa ACP, Lima AP, Teixeira RC, Pedrosa ICF. Sistema de informação da atenção básica-situação de saúde de um município de mato grosso. Cien Cuidado e Saúde. 2010 [acesso em 2014 ago 30]; v. 9, n. 1, p. 36-43. Disponível em: <http://www.periodicos.uem.br/ojs/index.php/ CiencCuidSaude/article/view/10527>

2. Benito GAV, Licheski AP. Sistemas de Informação apoiando a gestão do trabalho em saúde. Rev. bras. enferm., Brasília. 2009 [acesso em 2014 set 02]; v. 62, n. 3. Disponível em: $<$ http://www.scielo.br/scielo.php?script=sci arttext\&pid=\$003 471672009000300018\&lng=en\&nrm=iso $>$.

3. Ministério da Saúde (BRASIL), Secretaria do Estado da Paraíba. Guia de Atenção Básica para gestores municipais de saúde 2013. Versão Eletrônica. 2013 [acesso em 2014 ago 28]. Disponível em: <http://cosemspb.org/wpcontent/uploads/2013/05/SESPB Guia Atencao Basica Gestores Munic Saude 2013.pdf>

4. Duarte MLC, Tedesco JR, Parcianello RR. O uso do sistema de informação na estratégia saúde da família: percepções dos enfermeiros. Rev. Gaúcha Enferm. [acesso em 2014 ago 29]; v. 33, n. 4, p. 111-17. Disponível em: <http://www.scielo.br/ scielo.php?script=sci arttext $\&$ pid $=\$ 19831447201200040001$ 4\&lng=en>

5. Marcolino JS, Scochi MJ. Informações em saúde: o uso do SIAB pelos profissionais das Equipes de Saúde da Família. Rev. Gaúcha Enferm. [acesso 2014 set 03]; v. 31, n. 2, p. 314-20. Disponível em: <http://www.scielo.br/scielo.php?script=sci_ arttext\&pid=S1983-14472010000200016\&lng=en>.

6. Lima CRA, Schramm JMA, Coeli CM, Silva MEM. Revisão das dimensões de qualidade dos dados e métodos aplicados na avaliação dos sistemas de informação em saúde. Cad. Saúde Pública. 2009, n. 25, v. 10, p. 2095-2109.

7. Ministério da saúde (BRASIL). Manual de Implantação. Saúde Sistema E-SUS Atenção Básica. Brasília-DF. 2014.

8. Neto FRGX, Sampaio JJC. Análisis del proceso de trabajo de los gerentes en el territorio de la Estrategia de Salud de la Familia. Gerenc. Polit Salud Bogotá. Colômbia. [acesso em 2014 ago 10]; v.11, n.22, p.76-91. Disponível em: <http://rev_gerenc_polit_ salud.javeriana.edu.co/vol11_n_22/estudios_3.pdf>

9. Montenegro LC, Brito MJM, Cavalcante RB, Caram CS, Cunha GAM. Sistema de informação como instrumento de gestão: perspectivas e desafios em um hospital filantrópico. Journal of Health Informatics. 2013; v. 5, n. 1, p. 3-8.

10. Pinheiro ALS. Gerência de enfermagem em unidades básicas:a informação como instrumento para a tomada de decisão. Rev. APS. 2009 [acesso em 2014 ago 29]; v. 12, n. 3. Disponível em: <http://aps.ufjf.emnuvens.com.br/aps/article/view/333>

11. Sampaio RFE, Mancini MC. Estudos de revisão sistemática: um guia para síntese criteriosa da evidência científica. Rev. bras. fisioter. 2007; v. 11, n. 1, p. 83-9. 
12. Castro AA. Revisão Sistemática e Meta-análise. [Internet]. 2001; [acesso 2014 dez 16]. Available from: <http://metodologia.org/ wp-content/uploads/2010/08/meta1.pdf>.

13. Cavalcante RB, Bernardes MFVG, Gontijo TL, Guimarães EAA, Oliveira VC. Sistema de informação da atenção básica: potencialidades e subutilização no processo decisório. Cogitare enferm. 2013 [acesso em 2014 ago 28]; v. 18, n.3, p. 460- 67. 2013. Disponível em: $\quad<$ http://www.revenf.bvs.br/scielo. php?script=sci arttext\&pid=s141485362013000300006\&lng $=$ pt>

14. Radigonda B, Conchon MF, Carvalho WO, Nunes EFPA. Sistema de informação da atenção básica e sua utilização pela equipe de saúde da família: uma revisão integrativa. Londrina. Rev. Espaço para a Saúde. 2010; v. 12, n. 1, p. 38-47.

15. Vidor AC, Fisher PD, Bordin R. Utilização dos sistemas de informação em saúde em municípios gaúchos de pequeno porte. Rev Saude Publica. v. 45, n. 1, p. 24-30.

16. Maia LDG, Corrêa JPR, Lopes ACFMM, Neto JFR. Utilização do Sistema de Informação da Atenção Básica (SIAB) para o planejamento das ações pelas equipes da Estratégia de Saúde da Família do Município de Montes Claros (MG). Rev. Baiana de Saúde Pública. 2010; v.34, n.2, p. 359-370.

17. Souza RG, Rivemales MCC, Souza MKB. Sistema de informação da atenção básica como instrumento de gestão: estudo de caso em Santo Antônio de Jesus/BA. Online Brazilian Journal of Nursing. 2012; 1(1).

Publish in International Archives of Medicine

International Archives of Medicine is an open access journal publishing articles encompassing all aspects of medical science and clinical practice. IAM is considered a megajournal with independent sections on all areas of medicine. IAM is a really international journal with authors and board members from all around the world. The journal is widely indexed and classified Q1 in category Medicine. 